\title{
Importation of Good Governance at Local Self-government Institution in Bangladesh
}

\author{
Fakhrul Islam (Corresponding and Principal Author) \\ Assistant Professor, Department of Public Administration, \\ Shahjalal University of Science and Technology, \\ Sylhet, Bangladesh, \\ E-mail: fakhrul.bs11@gmail.com \\ Md. Amdadul Haque \\ Assistant Professor, Department of Political Studies, \\ Shahjalal University of Science and Technology, \\ Sylhet, Bangladesh. \\ E-mail: amdadulhaque85@yahoo.com
}

Doi:10.5296/ jpag.v5i4.8397 URL: http://dx.doi.org/10.5296/ jpag.v5i4. 8397

\begin{abstract}
The principle of good governance is difficult and controversial. Governance opens new space which provides a concept that allows us to discuss the role of government in coping with public issues and the contribution that other players may make. It opens one's mind to the possibility that groups in society other than government. Good governance is responsive to the present and future needs of society. Strengthening local governance can be ensured through the importation of the component of good governance at the local level. This paper intent to examine spaces where principles of good governance are required to apply to ensure better service delivery system at Union Parishad. This paper has been followed by social survey method. The data collection technique of this study has covered quantitative technique. Union Parishad as a local self government body ensuring community participations, people can approach and communicates clearly to their representatives and regularly issuing its progress report to the people for their transparency. Besides, dealing with convicted corruption was found most effective in manner.
\end{abstract}

Keywords: Local Self-government, Good Governance, Importation, Participation 


\section{Introduction}

Good governance is a term that has become a part of the vernacular of a large range of development institutions and other within the international arena. It has become a "hot" topic as evidence mounts on the critical role it plays in determining societal well-being (Graha, Amos, Plumptre, 2003). It may be usefully applied in different contexts - global, national, and institutional and local community. Understanding governance at the national and local level is made easier if one considers the different kinds of entities that occupy the social and economic landscape. It focuses areas of democratic governance, poverty reduction, energy and environment, as well as crisis prevention and recovery. Local Government is the yard stick of Good Governance (Begum, Kahn and Ahmed: 1998). In a democratic country, the Constitution ensures legal recognition of the local government by an act of the parliament or the incorporation of relevant provisions(Khan, 1997: 11). There is almost universal concurrence that local self government has important roles in stimulating and supporting within its boundary and it helps understood democratic spirit and values at the local level in Bangladesh (Islam, F. ;2015a). Thus local governance is important for promoting democratic representation and establishing entitlements, and local governance for improved provision of goods and services. Good governance is not only for a type of government and its related political values but also for certain kinds of additional components. It implies government that is democratically organized within a democratic political culture and with efficient administrative organizations, plus the right policies, particularly in the economic sphere (Smith, 2007). Good governance is responsive to the present and future needs of society (United Nations Economic and Social Commission for Asia and the Pacific). In this context, people's representative of the local government bodies must understand their governance role recognizes that the aim as a local government body is to achieve the best outcomes for their community. This means making well-informed decisions, quality investments and wise use of resources. Representatives of many Union Parishad seem to think that by levying local taxes to the full possible extent they risk losing their popularity and future electability and local elected officials are not all equally familiar with the rules for assessing and collecting taxes. Own-source revenues can provide a very effective and accountable Union Parishad-citizen relationship. Mobilization of own-source revenue promotes accountability and high levels of accountability also make citizens more willing to pay for services (Islam, F.; 2015b). It is possible to ensure at local level, through the importation of the component of good governance at the local level. Strengthening local governance can play a critical role in human development through decentralizing power from the centre to the provinces, districts and villages enables women and men to participate in decision-making directly, and to hold local officials and politicians more accountable to the communities and individuals they are meant to serve. Local governments can be more responsive to local needs, make better use of resources and direct them towards providing basic social services (UNDP00:2010). In practice, this means that peoples representative can determine what they need to do to ensure "the peace, order and good governance" of their constituency. There are many problems stimulate as barriers for good governance. To ensure sound local development action should be taken to work towards achieving good governance (Ara and Rahman, 2006). However, this paper is intent to explore the spaces of good governance to be imported for 
wanting and absence of these, the Union level are not performing effectively. Besides, this paper focuses to provide an inclusive course of action to ensure a participatory, responsive and effectiveness in service delivery at local level.

\section{Problem Statement}

Bangladesh as part of the Indian sub-continent shares the common history and legacy of local government with India and Pakistan. Till 1947 Bangladesh was part of the British Indian province of Bengal and Assam. It became part of Pakistan since 1947 and came to be known as East Pakistan. It becomes a sovereign and independent state after nine month long armed struggle in 1971. Local government Institutions (LGIs) in Bangladesh has history of hundreds of years in its credit. In spite of long history, it is still considered to be weak, underdeveloped, emaciated and feeble as social and political institutions as well as ineffective in dispensing goods and services to its citizen (Panday and Ahmed, 2011).

Bangladesh inherited a colonial Local Government structure since it was under the British $R a^{l} j$ for two hundred years and under Pakistan for about 24 years. The local government structure that the country inherited underwent different changes during the British and Pakistani rules. Bangladesh was born in revolutionary popular struggle. It began as a democratic nation (Barkdull, 2005: 374). It has a long history of fighting for democracy. The people of Bangladesh have repeatedly shown their desire functioning legitimate representative democracy (Barkdull, 2005: 393). Therefore, after independence, there had been several changes made to the structure of the local government bodies to ensure democratic practices at the root level. Different governments brought about changes in the structure of the local government bodies in the name of decentralization to ensure peoples spontaneous participation. Since the emergence of Bangladesh it can be pointed out that, units are being used by the periodical government for its own political gains (Rahman and Zaman: 2004). It can be asked whether all the initiatives were taken to make local government bodies strong and powerful. As a matter of fact, exploring the true motive behind different initiatives of the government is not an easy task. But, an effort can be made to explore the amount of political space that has been given by the central government to local structures to function independently. In fact the LGIs (Local Government Institutions) in Bangladesh had never been established as "self-governing" bodies in its true sense. Rather, these bodies have been considered as an extension of the central government where local people did not get enough opportunity to participate. Central government's intrinsic motive to control the management of the local government bodies has made these bodies institutionally and financially weak and non-credible. As a matter of fact, most changes were politically motivated, whose intention was to make a strong political base of the central government at the local level. Another important issue is that no decentralization initiative was based on wider consultation with people. Rather, in 1990 basis of implementation of decentralization policy was a set of recommendations given by the government appointed commission namely

\footnotetext{
1 The British Raj was the British rule in the Indian subcontinent between 1858 and 1947. The term can also refer to the period of dominion.
} 
as Huda Commission1991, Rahmat Ali Committee 1997, and Sawkat Ali Committee 2007. The recommendations made by those committees were not implemented by the governments in full. Only few of the selected recommendations were implemented which did not brought major changes as expected. The latest legislations of LGIs were brought by the Caretaker government in 2008 on the basis of the recommendations made by Sawkat Ali Committee. New legislations were passed in the form of ordinances on City Corporation, Municipalities, Upazila Parrishad and Union Parishad. The newly elected government in 2008 did not ratify those ordinances and thus those ordinances lost the spirit of law after the expiry of thirty days of the $9^{\text {th }}$ parliament in 2009. There were legal vacuum for about six months and by 2009 new legislations were passed but many of the provisions included in the previous ordinances were omitted.

In spite of being the breeding ground of democratic practice, Local Government system did not nursing properly in terms of practicing People participation, consensus oriented, accountable, transparent, responsive, effective and efficient, equitable and inclusive principles as well as not yet been followed the rule of law. So it has been obvious that, there were no initiatives commencing good governance at local level in Bangladesh. It has not yet been settled down in a rigid and strong manner in terms of ensuring good governance at local level in Bangladesh. Union Parishad as lowest democratic tiers in local government system has been playing vital role for practicing democracy at the local level without interval since the independence of Bangladesh. And the components of Good Governance must be ensured with the democratic flow to get an effective feedback from every sphere of society.

If government is not providing the quality of life that you think you and your fellow citizens deserve, it most likely has to do with good governance or a lack there of.How easy is it for you as a citizen to keep track of whether governments followed through on promises made during elections? Is it clear what was promised, where the money is coming from, when it will be done, who is responsible? Is the government delivering service such as education and health care to citizens in accordance with the needs and available budget? Is it collecting revenues honestly, investing those resources wisely and managing public goods for the benefit of all? Are they free of corruption and do they help built trust between citizens and the government? These are the baring questions today that must be meeting with reasonable and pragmatic answer through the study to fulfill the vacuum. Good governance has eight major characteristics. It is participatory, consensus oriented, accountable, transparent, responsive, effective and efficient, equitable and inclusive and follows the rule of law. It assures that corruption is minimized, the views of minorities are taken into account and that the voices of the most vulnerable in society are heard in decision-making. It is also responsive to the present and future needs of society. Because it is very important to explore "How people are ruled, how the affairs of the state are administrated and regulated..... nation system of politics...in relation to public administration and law"(Landell Mills and Serageldin 1991: 304). There for, it significantly carries to know whether component of good governance is possible to apply and thus, the reality can be distinguished and the necessary measure as guidelines can be sort out for ensuring Good Governance at local level. 


\section{Macrothink}

\section{Methodology}

This research has been based on the explanatory and descriptive design where survey method has been used to collect information and data. Both of quantitative and qualitative methods have been applied for the study. Quantitative research has been applied as it helps gathering numerical data and analyzes variables of numeric data statistically to provide measurable evidence regarding vacuum space in Union Parsishad where components of good governance can be imported.

As a part of survey, structured and open ended questionnaire has been prepared to collect data through face-to-face interview. Survey has been conducted over 58 respondents including people's representatives and general people of Union Parishad where 13, the entire representatives including Chairman of Kamarchak Union Parisahd at Mulbibazr, have been surveyed. On the other side, non probability convenience sampling methods has been followed for the 45 respondents from general people.

In this research, primary data of this research have been collected from the representatives and from the general people and the pertinent secondary information was accumulated from the published books, relevant articles, newspapers, different position papers and relevant websites. Besides, a significant portion of the information has been gathered from literature review. Finally, collected data have been characteristically classified, and then statistical method (e.g. percentage analysis and SPSS) has been applied on them.

\section{Data Presentation and Analysis:}

Table-1:Categories of the respondent

\begin{tabular}{|c|c|c|c|c|c|}
\hline & & Frequency & Percent & Valid Percent & $\begin{array}{l}\text { Cumulative } \\
\text { Percent }\end{array}$ \\
\hline \multirow[t]{4}{*}{ Valid } & Member of union parishad & 9 & 15.5 & 15.5 & 15.5 \\
\hline & $\begin{array}{l}\text { General people of union } \\
\text { parishad }\end{array}$ & 48 & 82.8 & 82.8 & 98.3 \\
\hline & Chairman of union parishad & 1 & 1.7 & 1.7 & 100.0 \\
\hline & Total & 58 & 100.0 & 100.0 & \\
\hline
\end{tabular}

Sources: Field Data, collected from Kamarchak Union Parisahd at Mulbibazr, January-February, 2015 
Table -1 shows the data type collected from a chairman, 09 members and 48 general people of a union parishad.

Table-2: How often are council meetings held?

\begin{tabular}{|l|l|l|l|l|}
\hline & Frequency & Percent & Valid Percent & $\begin{array}{l}\text { Cumulative } \\
\text { Percent }\end{array}$ \\
\hline Valid $\quad$ More than once a month & 4 & 6.9 & 6.9 & 6.9 \\
Once a month & 27 & 46.6 & 46.6 & 53.4 \\
Once every two months & 2 & 3.4 & 3.4 & 56.9 \\
Once a year & 5 & 8.6 & 8.6 & 65.5 \\
Don't know & 58 & 100.0 & 100.0 & 100.0 \\
Total & & 34.5 & 34.5 & \\
\hline
\end{tabular}

Sources: Field Data, collected from Kamarchak Union Parisahd at Mulbibazr, January-February, 2015

The table- 2 presented data that the majority of respondents $(46.6 \%)$ mentioned about the monthly meeting of union parishad and $34.5 \%$ of respondents mentioned they do not informed about union council meeting.

Table-3 Forums for community participations

\begin{tabular}{|ll|l|l|l|l|}
\hline & Frequency & Percent & Valid Percent & $\begin{array}{l}\text { Cumulative } \\
\text { Percent }\end{array}$ \\
\hline Valid $\quad$ Ward committees & 24 & 41.4 & 41.4 & 41.4 \\
No forums exist & 2 & 3.4 & 3.4 & 44.8 \\
Don't know & 32 & 55.2 & 55.2 & 100.0 \\
Total & 58 & 100.0 & 100.0 & \\
\hline
\end{tabular}




\section{Macrothink}

Journal of Public Administration and Governance ISSN 2161-7104 2015, Vol. 5, No. 4

Sources: Field Data, collected from Kamarchak Union Parisahd at Mulbibazr, January-February, 2015

The table-3shows that,55.2\% of the respondents have no idea about the existence of forums for community participations in union level and $41.4 \%$ of the respondents have information about the role of ward committees for community participations in union level.

Table-4 Attendance in the community forums

\begin{tabular}{|c|c|c|c|c|c|}
\hline & & Frequency & Percent & Valid Percent & $\begin{array}{l}\text { Cumulative } \\
\text { Percent }\end{array}$ \\
\hline \multirow[t]{6}{*}{ Valid } & Never & 41 & 70.7 & 70.7 & 70.7 \\
\hline & Once & 3 & 5.2 & 5.2 & 75.9 \\
\hline & Twice & 6 & 10.3 & 10.3 & 86.2 \\
\hline & Thrice & 3 & 5.2 & 5.2 & 91.4 \\
\hline & All & 5 & 8.6 & 8.6 & 100.0 \\
\hline & Total & 58 & 100.0 & 100.0 & \\
\hline
\end{tabular}

Sources: Field Data, collected from Kamarchak Union Parisahd at Mulbibazr, January-February, 2015

In response to the question about participation at community forum, the table- 4 shows that $70.7 \%$ of the respondents never attended in and above $5.2 \%$ respondents attended more than once in the community forum's meeting so far. 
Table-5 Effectiveness of the forums for community participation

\begin{tabular}{|c|c|c|c|c|c|}
\hline & & Frequency & Percent & Valid Percent & $\begin{array}{l}\text { Cumulative } \\
\text { Percent }\end{array}$ \\
\hline \multirow[t]{4}{*}{ Valid } & Non existent & 34 & 58.6 & 58.6 & 58.6 \\
\hline & Effective & 19 & 32.8 & 32.8 & 91.4 \\
\hline & Very effective & 5 & 8.6 & 8.6 & 100.0 \\
\hline & Total & 58 & 100.0 & 100.0 & \\
\hline
\end{tabular}

Sources: Field Data, collected from Kamarchak Union Parisahd at Mulbibazr, January-February, 2015

It is apparent from the table-5 that $58.6 \%$ of the respondents do not think as effective for community participation. In contrary about $40 \%$ of the respondents do think it has effectiveness to ensure community participation in Union Parishad.Table-6 Human resources capacity

\begin{tabular}{|ll|l|l|l|l|}
\hline & & Frequency & Percent & Valid Percent & $\begin{array}{l}\text { Cumulative } \\
\text { Percent }\end{array}$ \\
\hline Valid $\quad$ Moderately least important & 13 & 22.4 & 50.0 & 50.0 \\
& Fairly important & 5 & 8.6 & 19.2 & 69.2 \\
& Moderately important & 3 & 5.2 & 11.5 & 80.8 \\
& Most important & 5 & 8.6 & 19.2 & 100.0 \\
Missing & System & 26 & 44.8 & 100.0 & \\
Total & & 32 & 55.2 & & \\
\hline
\end{tabular}

Sources: Field Data, collected from Kamarchak Union Parisahd at Mulbibazr, 
January-February, 2015

It is apparent from the table- 6 that $55.2 \%$ of the respondents mentioned community forum is most important and the rest of the respondents have more or less opinion that community forum increasing capacity of manpower at local level.

Table-7 Credibility of forums

\begin{tabular}{|c|c|c|c|c|c|}
\hline & & Frequency & Percent & Valid Percent & $\begin{array}{l}\text { Cumulative } \\
\text { Percent }\end{array}$ \\
\hline \multirow[t]{6}{*}{ Valid } & Least important & 7 & 12.1 & 26.9 & 26.9 \\
\hline & Moderately least important & 7 & 12.1 & 26.9 & 53.8 \\
\hline & Fairly important & 5 & 8.6 & 19.2 & 73.1 \\
\hline & Moderately important & 4 & 6.9 & 15.4 & 88.5 \\
\hline & Most important & 3 & 5.2 & 11.5 & 100.0 \\
\hline & Total & 26 & 44.8 & 100.0 & \\
\hline Missing & System & 32 & 55.2 & & \\
\hline Total & & 58 & 100.0 & & \\
\hline
\end{tabular}

Sources: Field Data, collected from Kamarchak Union Parisahd at Mulbibazr, January-February, 2015

It is found that $55.2 \%$ the majority of the respondents mentioned local community fouram has enough credibility and the rest of the respondents motioned about the same (Table-7). 
Table-8. Recommendations of ward committee to council

\begin{tabular}{|l|l|l|l|l|}
\hline & Frequency & Percent & Valid Percent & $\begin{array}{l}\text { Cumulative } \\
\text { Percent }\end{array}$ \\
\hline Valid $\quad$ Don't know & 22 & 37.9 & 37.9 & 37.9 \\
Never & 10 & 17.2 & 17.2 & 55.2 \\
Rarely & 15 & 25.9 & 25.9 & 81.0 \\
Regularly & 11 & 19.0 & 19.0 & 100.0 \\
Total & 58 & 100.0 & 100.0 & \\
\hline
\end{tabular}

Sources: Field Data, collected from Kamarchak Union Parisahd at Mulbibazr, January-February, 2015

It is apparent from the table- 8 that $37.9 \%$ the majority of the respondent don't found any attempt to implement the recommendation of ward committee by the Union Parishad and $25.9 \%$ of the respondents mentioned rarely it has been implemented.

Table-9. Resources to promote community participation

\begin{tabular}{|ll|l|l|l|l|}
\hline & Frequency & Percent & Valid Percent & $\begin{array}{l}\text { Cumulative } \\
\text { Percent }\end{array}$ \\
\hline Valid $\quad$ Travel resources & 1 & 1.7 & 1.7 & 1.7 \\
A venue & 21 & 36.2 & 36.2 & 37.9 \\
Catering resources & 3 & 5.2 & 5.2 & 43.1 \\
Administrative resources & 4 & 6.9 & 6.9 & 50.0 \\
None & 29 & 50.0 & 50.0 & 100.0 \\
Total & 58 & 100.0 & 100.0 & \\
\hline
\end{tabular}




\section{Macrothink}

Journal of Public Administration and Governance ISSN 2161-7104 2015, Vol. 5, No. 4

Sources: Field Data, collected from Kamarchak Union Parisahd at Mulbibazr, January-February, 2015

According to table-9, the majority of the respondent $50 \%$ noticed that there is no provision of increasing community participation at the local level but $36.2 \%$ on the other hand mentioned a venue always available for any meeting at Union Prasisahd.

Table-10 Issuing progress report of Union parishad to people

\begin{tabular}{|ll|l|l|l|l|}
\hline & Frequency & Percent & Valid Percent & $\begin{array}{l}\text { Cumulative } \\
\text { Percent }\end{array}$ \\
\hline Valid & Yes & 29 & 50.0 & 50.0 & 50.0 \\
No & 13 & 22.4 & 22.4 & 72.4 \\
Don't know & 16 & 27.6 & 27.6 & 100.0 \\
Total & 58 & 100.0 & 100.0 & \\
\hline
\end{tabular}

Sources: Field Data, collected from Kamarchak Union Parisahd at Mulbibazr, January-February, 2015

The table-10 shows that, half of the respondent mentioned that progress report of union parisahd has been issued regularly, $22.4 \%$ of the respondent did not agree with it and $27.6 \%$ of the respondents were found no knowledge about this.

Table-11. Annual report of Union Parishad distributed widely

\begin{tabular}{|c|c|c|c|c|c|}
\hline & & Frequency & Percent & Valid Percent & $\begin{array}{l}\text { Cumulative } \\
\text { Percent }\end{array}$ \\
\hline \multirow[t]{4}{*}{ Valid } & Yes & 32 & 55.2 & 55.2 & 55.2 \\
\hline & No & 10 & 17.2 & 17.2 & 72.4 \\
\hline & Don't know & 16 & 27.6 & 27.6 & 100.0 \\
\hline & Total & 58 & 100.0 & 100.0 & \\
\hline
\end{tabular}

Sources: Field Data, collected from Kamarchak Union Parisahd at Mulbibazr, 
January-February, 2015

According to table-11, the majority 55.2\% of the respondent mentioned that union parisahd published its annual report, $17.2 \%$ of the respondent were not agree with it and $27.6 \%$ of the respondent were found whom did not have idea about it.

\section{Table-12. Regular Auditioning}

\begin{tabular}{|ll|l|l|l|l|}
\hline & Frequency & Percent & Valid Percent & $\begin{array}{l}\text { Cumulative } \\
\text { Percent }\end{array}$ \\
\hline Valid $\quad$ Yes & 16 & 27.6 & 27.6 & 27.6 \\
No & 10 & 17.2 & 17.2 & 44.8 \\
Don't know & 32 & 55.2 & 55.2 & 100.0 \\
Total & 58 & 100.0 & 100.0 & \\
\hline
\end{tabular}

Sources: Field Data, collected from Kamarchak Union Parisahd at Mulbibazr, January-February, 2015

The majority $55.2 \%$ of the respondent were found who did not have idea whether audit team visit or not, $27.6 \%$ of the respondent mentioned audit team visit regularly and $17.2 \%$ of the respondent denied it.

Table-13. Accessibility of people to the union council office

\begin{tabular}{|l|l|l|l|l|}
\hline & Frequency & Percent & Valid Percent & $\begin{array}{l}\text { Cumulative } \\
\text { Percent }\end{array}$ \\
\hline Valid $\quad$ Less accessible & 3 & 5.2 & 5.2 & 5.2 \\
Accessible & 5 & 8.6 & 8.6 & 13.8 \\
Moderately accessible & 21 & 36.2 & 36.2 & 50.0 \\
Very accessible & 27 & 46.6 & 46.6 & 100.0 \\
Others & 2 & 3.4 & 3.4 &
\end{tabular}


Table-13. Accessibility of people to the union council office

\begin{tabular}{|l|l|l|l|l|}
\hline & Frequency & Percent & Valid Percent & $\begin{array}{l}\text { Cumulative } \\
\text { Percent }\end{array}$ \\
\hline Valid $\quad$ Less accessible & 3 & 5.2 & 5.2 & 5.2 \\
Accessible & 5 & 8.6 & 8.6 & 13.8 \\
Moderately accessible & 21 & 36.2 & 36.2 & 50.0 \\
Very accessible & 27 & 46.6 & 46.6 & 96.6 \\
Others & 2 & 3.4 & 3.4 & 100.0 \\
Total & 58 & 100.0 & 100.0 & \\
\hline
\end{tabular}

Sources: Field Data, collected from Kamarchak Union Parisahd at Mulbibazr, January-February, 2015

According to table-13, the majority of the respondent mentioned that union parisahd is very accessible $(46.6 \%)$, moderately accessible $(36.2 \%)$ and accessible $(8.6 \%)$ by the general people.

Table-14 System of receiving public argument

\begin{tabular}{|ll|l|l|l|l|}
\hline & Frequency & Percent & Valid Percent & $\begin{array}{l}\text { Cumulative } \\
\text { Percent }\end{array}$ \\
\hline Valid & Yes & 22 & 37.9 & 37.9 & 37.9 \\
& No & 30 & 51.7 & 51.7 & 89.7 \\
& Others & 6 & 10.3 & 10.3 & 100.0 \\
& Total & 58 & 100.0 & 100.0 & \\
\hline
\end{tabular}

Sources: Field Data, collected from Kamarchak Union Parisahd at Mulbibazr, January-February, 2015 


\section{Macrothink}

According to table-14, there is no any system of receiving the public arguments $(51.7 \%)$ ont other hand $37.9 \%$ of the respondent mentioned positive about this system.

Table-15 Development Activities regarding Housing and Roads

\begin{tabular}{|ll|l|l|l|l|}
\hline & Frequency & Percent & Valid Percent & $\begin{array}{l}\text { Cumulative } \\
\text { Percent }\end{array}$ \\
\hline Valid & Very poor & 4 & 6.9 & 6.9 & 6.9 \\
& Poor & 21 & 36.2 & 36.2 & 43.1 \\
Fair & 21 & 36.2 & 36.2 & 79.3 \\
Good & 12 & 20.7 & 20.7 & 100.0 \\
Total & 58 & 100.0 & 100.0 & \\
\hline
\end{tabular}

Sources: Field Data, collected from Kamarchak Union Parisahd at Mulbibazr, January-February, 2015

It is apparent from the table-15 that majority of the respondent mentioned development activities at Unon Parishad two opinion as fair and poor but very close number of the majority of the respondent mentioned it is good.

\section{Table-16 Preservation of environment and Recreation facilities}

\begin{tabular}{|l|l|l|l|l|}
\hline & Frequency & Percent & Valid Percent & $\begin{array}{l}\text { Cumulative } \\
\text { Percent }\end{array}$ \\
\hline Valid $\quad$ Very poor & 24 & 41.4 & 41.4 & 41.4 \\
Poor & 18 & 31.0 & 31.0 & 72.4 \\
Fair & 11 & 19.0 & 19.0 & 91.4 \\
Good & 5 & 8.6 & 8.6 & 100.0 \\
Total & 58 & 100.0 & 100.0 & \\
\hline
\end{tabular}


Sources: Field Data, collected from Kamarchak Union Parisahd at Mulbibazr, January-February, 2015

From the table-16, it is found that majority of the respondent $41.4 \%$ of the respondent mentioned preservation of environment and recreation facilities is very poor at this union and second height number of the respondent also mentioned about the same opinion.

Table-17 Supporting cooperative societies and volunteer organization

\begin{tabular}{|l|l|l|l|l|}
\hline & Frequency & Percent & Valid Percent & $\begin{array}{l}\text { Cumulative } \\
\text { Percent }\end{array}$ \\
\hline Valid $\quad$ Very poor & 23 & 39.7 & 39.7 & 39.7 \\
Poor & 17 & 29.3 & 29.3 & 69.0 \\
Fair & 8 & 13.8 & 13.8 & 82.8 \\
Good & 7 & 12.1 & 12.1 & 94.8 \\
Excellent & 3 & 5.2 & 5.2 & 100.0 \\
\hline
\end{tabular}

Sources: Field Data, collected from Kamarchak Union Parisahd at Mulbibazr, January-February, 2015

The table-17 shows that, majority of the respondent $39.7 \%$ of the respondent mentioned supporting cooperative societies and volunteer organization is very poor at this union and second height number of the respondent also mentioned about the same opinion. 
Table-18. Nature of Corruption

\begin{tabular}{|l|l|l|l|l|}
\hline & Frequency & Percent & Valid Percent & $\begin{array}{l}\text { Cumulative } \\
\text { Percent }\end{array}$ \\
\hline $\begin{array}{l}\text { Valid } \begin{array}{l}\text { Nepotism in employment of } \\
\text { officials }\end{array} \\
\begin{array}{l}\text { Mal-administration of public } \\
\text { funds and recourses }\end{array}\end{array}$ & 27.6 & 27.6 & 27.6 \\
Others & 23 & 39.7 & 39.8 & 60.3 \\
Total & 58 & 100.0 & 100.0 & 100.0 \\
\hline
\end{tabular}

Sources: Field Data, collected from Kamarchak Union Parisahd at Mulbibazr, January-February, 2015

According to table-18, nepotism in employment at union parsiahd were found $27.6 \%$, mal-administration of public funds and resources were found $32.8 \%$ and others forms of corruption were found $39.7 \%$ from the field data.

Table-19 Consequences of alleged corruption in the council

\begin{tabular}{|ll|l|l|l|l|}
\hline & Frequency & Percent & Valid Percent & $\begin{array}{l}\text { Cumulative } \\
\text { Percent }\end{array}$ \\
\hline Valid $\quad$ Subjected to disciplinary action & 35 & 60.3 & 60.3 & 60.3 \\
Investigated & 6 & 10.3 & 10.3 & 70.7 \\
No Consequences & 9 & 15.5 & 15.5 & 86.2 \\
Don't know & 8 & 13.8 & 13.8 & 100.0 \\
Total & 58 & 100.0 & 100.0 & \\
\hline
\end{tabular}

Sources: Field Data, collected from Kamarchak Union Parisahd at Mulbibazr, January-February, 2015 
The table-19 show that $60.3 \%$ of the respondent mentioned that it is found form there observation alleged corruptions in this council go under disciplinary action and $10.3 \%$ of the respondent mentioned it must be investigated.

Table-20 Rate the effectiveness in dealing with convicted of corruption

\begin{tabular}{|ll|l|l|l|l|}
\hline & Frequency & Percent & Valid Percent & $\begin{array}{l}\text { Cumulative } \\
\text { Percent }\end{array}$ \\
\hline Valid $\quad$ Least effective & 13 & 22.4 & 22.4 & 22.4 \\
Moderate effective & 11 & 19.0 & 19.0 & 41.4 \\
Effective & 6 & 10.3 & 10.3 & 51.7 \\
Fairly effective & 12 & 20.7 & 20.7 & 72.4 \\
Most effective & 16 & 27.6 & 27.6 & 100.0 \\
Total & 58 & 100.0 & 100.0 & \\
\hline
\end{tabular}

Sources: Field Data, collected from Kamarchak Union Parisahd at Mulbibazr, January-February, 2015

According to table-20, dealing with convicted corruption was found most effective in manner from the majority $(27.6 \%)$ of the respondent, $20.7 \%$ of the respondent were mentioned fairly effective and a large portion $22.4 \%$ of the respondent mention dealing were least effective in manner.

\section{Findings and Discussion}

Following extensive research and consultation, it is evident that Union Parishad has been conducting regular meeting regarding various issue and factors. This framework emphasizes the importance of good governance to the wider outcomes of good management, good performance, and good public engagement. It can be fulfilled through the forums that will ensure community participations at union level. This framework should have been well-informed to the general people of that constituency. But very few of people were found in that area those are well informed and participated. It is a process where people can approach and communicates clearly to their representatives the assurance on their own arrangements. But majority of them were found did not have experience to take part more than once. In order to search for the reason, it was evident among the respondents that community forums are not effective to ensure participation in decision making process in 
union level in Bangladesh. But through this framework of participation, people urge local authorities to prepare a governance statement in order to report publicly on the extent to which they comply with their own code of governance on an annual basis, including how they have monitored and evaluated the effectiveness of their governance arrangements in the year, and on any planned changes in the coming period. As, it is found from the opinion of the respondents, it has enough reliability. In contrary, those who do not relay on it they argued that their demands and opinion never been reflected.

The annual governance statement should provide a brief communication regarding the review of governance that has taken place and the role of the governance structures involved (such as the authority and the audit and other committees).Union parisahd regularly issues its progress report to the people for their transparency and accountability although a large number of people don't have idea on it. As a matter of best practice of good governance, it should be accessible and should normally be approved open admittance for the people. Union Parishad is found very cordial to the people of that area as good governance indicates developing, communicating and embedding codes of conduct, defining the standards of behavior for members and staff. However, Union Parisahd had found no provision of receiving complain and demands of local people.

Development actives must be the authority's vision and its implications must be regarded as the authority's achievement and ensuring effective management of change and transformation of the situations. Environmental management is the foremost part of development but it is a outrageous matter that it is found is very poor at this union. Besides, cooperative society actives and volunteer organization is found very substandard.

From the observation, it is found that people and their representative of union parisad are aware of corruption but there are various forms of corruption still exist at this union parisahd. It is obvious that, enhancing the accountability for service delivery and effectiveness of other service providers at Union Parishad, corruption must be reduced and control through various ways like disciplinary action and investigation. But a large number of people are found don't know what measure and how it can be protected. However, the process of dealing with convicted corruption was found most effective in manner as the opinion of the majority although a large number of the people have mentioned measures are not effective to the convicted corruption at union parisahd.

\section{Conclusion and Recommendations}

Good governance mediates differing interests to reach a broad consensus on what is in the best interest of the group and, where possible, on policies by their participation. Participation by both men and women is a key cornerstone of good governance. Participation could be either direct or through legitimate intermediate institutions or representatives. In the UP Act of 2009, there is a provision of constituting a Ward Shava (Ward Meeting) in each ward consisting of all voters enlisted in the voter lists which would be chaired by the elected member of the concerned ward. And, good governance requires fair legal frameworks that are enforced impartially. If this provision is implemented in letter and spirit, it would certainly open up new avenue for the people to take part in the activities of the UP. It is important to 
mention here that practice of holding up meeting of the Ward Meeting at the ward level has just started. Besides, for ensuring smooth functioning of the activities of the local and urban-local bodies, there is a provision of formation of standing committees in each body. At the UP level, there is a provision of formation of thirteen standing committees. Good governance requires that institutions and processes try to serve all stakeholders within a reasonable timeframe. A society's well being depends on ensuring that all its members feel that they have a stake in it and do not feel excluded from the mainstream of society. This requires all groups, but particularly the most vulnerable, have opportunities to improve or maintain their well being.

Local governments should really be regarded as 'governments' of small areas and not merely an agent or client of central government and to be allowed required freedom and autonomy within its own domain, otherwise its full capacity will not be harnessed and dedicated leadership will not emerge and develop from the soil. Union prishad's budgetary allocation mobilizes their own resources too and they are also legally bound to prepare and pass their own annual budgets that must be disclosed to the people. But plans and budgets are needed to be integrated with the national budget and national plan.

Processes, institutions and information of Union Praishad are to be directly accessible to those concerned with them, and enough information to be provided to understand and monitor them. Its legal frameworks should be fair and enforced impartially, particularly the laws on human rights.

\section{Reference}

Barkdull, John (2005); "Democracy Promotion in Bangladesh: The Role of outside Actors" in Journal of the Asiatic Society of Bangladesh, Golden jubilee volume.

Begum Nelufar, Khan Abdullah M and Ahmed Saifuddin (1998) “Luk Prosason o Bangladesh: Prasongik Babna" (Public Administraton and Bangladesh: Administrative Thinking) Obosor Publication, Sutrapur Dhaka,

Graha, Amos, Plumptre, 2003. Principles for Good Governance in the $21^{\text {st }}$ Century Policy Brief No.15 August http://unpan1.un.org/intradoc/groups/public/documents/UNPAN/UNPAN011842.pdf

Islam, F. (2015a). The role of local self-government institution for deepening democracy at the grass-root level in Bangladesh. Journal of Public Administration and Policy Research, $7(2)$, 29

38.http://www.academicjournals.org/journal/JPAPR/how-to-cite-article/5FCF3FE51541

Islam, F. (2015b). Minimizing Central-Local Relation using Local Resource Mobilization in Bangladesh. Journal of Public Administration and Governance, 5(2). http://macrothink.org/journal/index.php/jpag/article/view/7561/6372

DOI: http://dx.doi.org/10.5296/jpag.v5i2.7561 


\section{Macrothink}

Journal of Public Administration and Governance ISSN 2161-7104 2015, Vol. 5, No. 4

Khan, Mohmmad Mohabbat,1991. "Politics of Administrative Reform: A Case Study of Bangladesh", Ashis Publication House, New Dlhi.

Landell Mill.P. and Serageldin.I(1991). "Governance and the External Factors,Processing on the world Bank Annual Conference on Development Economies, Washington D.C. The World Bank.

Panday and Ahmed (2011). "Issues and Challenges of Good Governance in Bangladesh: Local Governance Perspectives" Paper presented in the seminar of Rastra Biggan Samity Zila Parishad Auditorium, Sylhet

Rahman, Moksusder M and Zaman, Nasima (2004); "Politics and Local Self-Government in Bangladesh: The Historial Perspeative" in Journal of Sociol Studies.

Smith,B.C 2007, "Good Governance and Development" Published by: Taylor \& Francis, http://www.jstor.org/stable/27751987?seq=1\#page_scan_tab_contents

UNDP Contribution to Strengthening Local Governance Participation, 2010, A.K. Office Supplies Litd, 